\title{
LIMITED LIABILITY OF SHAREHOLDERS IN REAL ESTATE INVESTMENT TRUSTS AND THE CONFLICT OF LAWS
}

\section{INTRODUCTION}

Although recent tax legislation ${ }^{1}$ has given real estate investors cause to reconsider the "Massachusetts Trust" as an advantageous form of business, ${ }^{2}$ potential trust investors and promoters must realize that several states do not fully recognize the common law trust as a business form. ${ }^{3}$ These states maintain that a business organization seeking limited liability for its investors can do so only through statutory sanction, i.e., by incorporation or hmited partnership; trust investors are held individually hable as members of a partnership. ${ }^{4}$

Because most states recognize limited liability for investor-beneficiaries of a business trust, ${ }^{5}$ any resurgence of the business trust probably will be confined to organization in such states. Nevertheless, should trust activities become involved with states having laws adverse to the business trust, conflict of laws problems seem likely to arise. In particular, it must be determined whether trust investors are to be given limited liability in view of possible connections with states denying such immunity. ${ }^{6}$

This comment considers the problem of investor hability in four different situations. It is assumed in each situation that a business trust is formed and transacts business in a state $X$, that trust beneficiaries are permitted limited liability under the domestic laws of $X$, and that the trust instrument provides for limited habihty. ${ }^{7} Y$ is a state in which a business trust cannot be created to give immunity to its investors. The first three situations are determined by combinations of the variables of whether suit is in state $X$ or state $Y$, and whether the trust transacts business in $Y$. The fourth situation is presented when a third state, $Z$, has jurisdiction of the suit but has no other relation to the hitigation. Other

1 INT. REv. CODE OF 1954, \$§ 856-58 provide for "Real Estate Investment Trusts" to avoid taxation as a corporation. This comment does not deal with tax problems arising from this legislation.

2 Since the decision in Morrissey v. Commissioner, 296 U.S. 344 (1935), there had been no federal tax advantage in using the trust form, as the business trust was there held taxable as a corporation.

3 Rubens v. Costello, 75 Ariz. 5, 251 P.2d 306 (1952); Willey v. W. J. Hoggson Corp., 90 Fla. 343, 106 So. 408 (1925); McClaren v. Dawes Elec. Sign \& Mfg. Co., 86 Ind. App. 196, 156 N.E. 584 (1927) ; Ing v. Liberty Nat'l Bank, 216 Ky. 467, 287 S.W. 960 (1926); Ors. Omlo AtT'y Gen, 1023 (1919). See generally WarRen, Corporate Advantages Without IncorporaTION 383-404 (1929); ADnot., 156 A.L.R. 22, 104-09 (1.945).

4 See note 3 supra. Washington does not recognize business trusts as common law trusts, but still affords limited liability to trust beneficiaries by analogizing the business trust to a corporation. WASH. REv. CODE \$23.90.040(4) (1959).

5 See 2 Bogert, Trusts \& Trustees 362-63 (1953). Both Texas and Kansas formerly denied limited liability to business trust beneficiaries but recently have enacted legislation affording beneficiary immunity. Tex. Rev. Crv. Stat. art. 6138A (1962); Kan. Gen. Stat. ANn § 17-2028 (Supp. 1961).

6 See generally Note, The Real Estate Investment Trust in Multistate Activity, 48 Vs. L. REv. 1125 (1962).

7 Ordinarily, the trust instrument, in addition to providing for shareholder immunity, directs the trustees to provide for himited liability in all contracts negotiated in behalf of the trust. See Magruder, The Position of Shareholders in Business Trusts, 23 CoLvM. L. REv. 423, 433 n.46 (1923). 
factors, such as the residences of the parties, are considered as they arise in each of the situations.

The four situations are:

(1) The $X$ trust transacts business in $Y$, and a beneficiary is sued in $X$ on the basis of a hability arising out of a $Y$ transaction.

(2) The trust transacts business in $Y$ and a benficiary is sued in $Y$.

(3) The trust transacts no business in $Y$ and a beneficiary is used in $Y$.

(4) The trust incurs a liabihity while transacting business in $Y$ and a beneficiary is sued in state $Z$.

Because few cases deal specifically with these problems, ${ }^{8}$ analogies must be drawn from the law relating to business associations in general. An understanding of the problem and its possible solutions will be enhanced by considering Professor Brainerd Currie's recently developed "governmental interest" theory..$^{9}$ In addition, it seems useful to pursue a more traditional mode of analysis, giving primary consideration to the objective of reliability in business planning.

Part I of this comment discusses broadly the substantive law of business trusts as formulated by both states $X$ and $Y$. Part II considers the basic principles of Currie's theory. Part III deals with the possibility of a more traditional choice of law rule. In part IV each of the four situations is analyzed.

\section{I}

\section{BUSINESS TRUSTS IN GENERAL}

\section{A. Domestic Law in State $X$}

State $X$ permits investors in business trusts to enjoy limited liability. This immunity, based on the common law trusts rule that a beneficiary is not responsible for liabilities incurred by a trustee acting in behalf of a trust, ${ }^{10}$ is not without restriction. As a general rule, "ultimate control" of the trust business must be

$8 \mathrm{An}$ analysis of conflict of laws problems relating to conventional common law trusts would not appear relevant to the present problem. With conventional trusts the conflicts problems seem to fall into two categories: (1) conflicts relating to laws of trust validity and distribution, and (2) conflicts relating to laws of trust administration. See generally LAND, TRUSTS IN THE CONFLICT OF LAws (1940). Moreover, the business trust is a form of voluntary investment for profit by the beneficiaries as distinguished from the general donee status of a conventional trust beneficiary. See 2 BogerT, TRUSTS \& TrUSTEES 359 (1953).

${ }^{\circ}$ Currie's theory has evolved from the following series of articles: Currie, Survival of Actions: Adjudication Versus Automation in the Conflict of Laws, 10 STAN. L. REv. 205 (1958); Currie, Married Women's Contracts: A Study in Confict-of-Laws Method, 25 U. CHI. L. Rev. 227 (1958); Currie, Notes on Methods and Objectives in the Conflict of Laws, 1959 DUKe L.J. 171; Currie, The Constitution and the Choice of Law: Governmental Interests and the Judicial Function, 26 U. CHI. L. REv. 9 (1958); Currie, The Constitution and the "Transitory" Cause of Action, 73 HaRv. L. Rev. 36, 268 (1959); Currie, The Silver Oar and All That: A Study of the Romero Case, 27 U. C\#r. L. REv. 1, 65-75 (1959); Hill, Governmental Interest and the Conflict of Laws-A Reply to Professor Currie, 27 U. CHI. L. Rev. 463 (1960); Currie, The Verdict of Quiescent Years: Mr. Hill and the Conflict of Laws, 28 U. Cm. L. REv. 258 (1961); Currie \& Schreter, Unconstitutional Discrimination in the Conflict of Laws: Equal Protection, 28 U. CHI. L. REv. 1 (1960); Currie \& Schreter, Unconstitutional Discrintination in the Conflict of Laws: Privileges and Immunities, 69 YaLE L.J. 1323 (1960).

See also Traynor, Is This Conflict Really Necessary?, 37 TEXas L. Rev. 657 (1959) ; Currie, Justice Traynor and the Conflict of Laws, 13 STAN. L. Rev. 719 (1961).

10 Williams v. Inhabitants of Milton, 215 Mass. 1, 102 N.E. 355 (1913). See Magruder, The Position of Shareholders in Business Trusts, 23 ColuM. L. REv. 423 (1923) ; Comment, Massachusetts Trusts, 37 YAIE L.J. 1103 (1928). 
vested in the trustees; if the beneficiaries undertake to run the business they may become individually liable. ${ }^{11}$ Various states also subject the business trust to some statutory regulation. ${ }^{12}$

In deciding that beneficiaries of a business trust shall not be held liable individually for trust activities, $X$ law has determined to enlarge the realm of those business associations in which investor immunity is afforded. While presumably this determination is, or once may have been, based on a policy of encouraging the transaction of business in the trust form, perhaps the most that can be said is that the policy of $X$ law is to recognize and accommodate to the reality that business is done in the trust form. ${ }^{13}$

\section{B. Domestic Law in State $Y$}

State $Y$ does not permit beneficiaries of business trusts to enjoy limited liability. States refusing immunity to trust investors are relatively few, ${ }^{14}$ and some are not exphicit in defining the extent to which the business trust is refused recognition. ${ }^{15}$ Presumably $Y$ policy is not opposed to limiting liability as such, for $Y$ states recoguize shareholder imunity for both foreign and domestic corporations. ${ }^{10}$

11 Among those states that apply the test of "ultimate control" to determine whether trust beneficiaries are liable for trust obligations, the particular attitude and criteria used in applying the test, i.e., the emphasis given to one factor or another of participation in and control of the organization's activities, can vary. Thus, choice of law problems could arise with respect to the laws of two $X$ states. These difficulties are likely to he minor, however, and in any event a few cases indicate that the law of the state of trust organization is to be applied in this situation. See Textile Properties, Inc. v. M. J. Whittall Associates, 282 N.Y. Supp. 17 (Sup. Ct. 1934) ; Marchulonis v. Adams, 97 W. Va. 517, 125 S.E. 340 (1924); cf. Schumann-Heink v. Folsom, 328 III. 321,159 N.E. 250 (1927).

In order for the trust to qualify under INT. REv. CODE of $1954, \S 856$ (a), it will have to meet a standard of centralized management generally the same as the "ultimate control" test. Under the tax regulations the trustee must have continuing exclusive autliority over management of the trust, trust property, and the disposition of trust property, with the shareholders being able only to elect or remove trustees, terminate the trust, or ratify trust amendments. Treas. Reg. \& 1.856-1(d) (1) (1962). It would seem likely for an $X$ state to uphold heneficiary immunity if the federal requirements are met.

12 See, e.g., Cat. Corp. Code $\S \S 23000-03$ (enacted in 1961); OkLa. Stat. ANN. tit. 60, § 174 (1949); WASE. REv. CODE § 23.90.040(4) (1959).

13 In its early development, the trust form was used by businessmen in Massachusetts secking to accumulate large land holdings, since the corporate device was not available for this purpose. The Massaclrusetts courts responded to the situation by allowing limited liahility for trust investors. Comment, Massachusetts Trusts, 37 YaLE L.J. 1103, 1106 (1928). It has bcen suggested, however, that limited liability was not the sole reason for using the busimess trust, for many Massachusetts organizations did not comply with the ultimate control test. Id. at 1120 n.76. On the other liand, when Texas began treating business trusts as partnerships they became virtually extinct. $I d$. at 1106 n.19.

14 See note 3 supra.

15 See Jones, Business Trusts in Florida-Liability of Shareholders, 14 U. FLA. L. REv. 1 (1961).

10 See, e.g., Ky. REv. STaT. $\$ \S 271.215, .990$ (1962). Furthermore, the state formerly having what seemed to be the strongest $Y$ policy lad recognized that a creditor by contract could agree not to hold the beneficiaries of a business trust individually liable. Shelton v. Montoya Oil \& Gas Co., 272 S.W. 222 (Tex. Civ. App. 1925), aff'd, 292 S.W. 165 (Coinm'n App. 1927). (Texas no longer denies beneficiaries imnunity. See note 5 supra.) Nevertheless, while most trust instruments provide that the trustee in all contracts shall insert a clause exonerating the beneficiaries, see note 7 supra, it appears that trustees frequently fail to put in these saving provisions, see Magruder, The Position of Shareholders in Business Trusts, 23 CoLum. L. Rev. 423, 433 (1923). In addition, apart from liabilities arising froin express contracts, the trust may also incur contract obligations arising by implication and tort liabilities. Sce Means v. Limpia Royalties, 115 S.W.2d 468 (Tex. Civ.App. 1938). 
A number of policy reasons for refusing investor immunity to the business trust have been advanced by Professor Edward Warren ${ }^{17}$ that seem to be a fair statement of $Y$ policy. ${ }^{18}$ Investor immunity, although desirable, is to be granted only on terms a legislature deems consistent with protecting creditors. ${ }^{19}$ In order for corporate shareholders to lave this advantage, the corporation subjects itself to various state regulations, such as filing annual reports. Furthermore, the grant of this advantage properly may be made a source of revenue to the state. ${ }^{20}$ The statutory advantages of a corporation or limited partnership should not be available to a business trust that in effect is circumventing these same statutes. ${ }^{21}$

\section{II}

\section{GOVERNMENTAI INTEREST THEORY}

Professor Currie's governmental interest theory ${ }^{22}$ begins with the assumption that a state has an interest in applying its own law and should do so when the facts of a particular case present a reasonable basis for furthering the state's pohicy. ${ }^{23}$ Under Currie's theory it is initially expected that the forum law is to be applied as a matter of course, even where foreign elements are present in the suit. Where it is suggested that a foreign law be applied, a court should deternine the nature of the policy underlying the forum law. If the relation of the forum to the case provides a legitimate basis for asserting an interest in applying its own policy, then the rule of decision under forum law should prevail, regardless of any interest of a foreign state. ${ }^{24}$ If the case does not present the forum with such an interest, then a similar analysis of the policy underlying the proposed foreign law is to be made. When a court determines that the forum has no interest in applying its own policy, but that the foreign state has, the foreign law should be applied. Where neither a foreign state nor the forum has an interest, forum law is to be applied as being the most convenient. In essence, Currie's theory emphasizes the primacy of forum law, referring to foreign law only when the forum cannot advance its own policies through applying its own laws.

The fact that results under Currie's theory may depend on whicl forum liears a particular case seemingly indicates unpredictability in choice of law situations.

17 Warren, Corporate Advantages Without Incorporation 383-404 (1929).

18 Cases establishing $Y$ policy are cited in note 3 supra.

19 WARREN, op. cit. supra note 17 , at 399.

20 Ibid.

21 A separate point of objection advanced by Warren-but one that seems relevant only to legislative approval of the trust form rather than adjudication of the liability of a shareliolder of an operating trust-is that to obtain limited liability the investors in a business trust must give up their right to control of the company. Id. at 398 . He argues that to afford efficient management and to prevent misapplication of funds, the shareholders should be able to exercise their own judgment in management affairs and effect a ehange of management sloould they desire to do so. Under the tax code a ehange of management by the shareholders appears permissible. See note 11 supra.

22 See note 9 supra.

23 Currie's article, Notes on Methods and Objectives in the Confict of Laws, 1959 DJke L.J. 171, presents a more detailed description of the governmental interest theory, and probably is the best summary of Currie's views.

24 Currie's approach presumes that it is not the judiciary's function to weigh the competing interests of different states. Currie, Notes on Methods and Objectives in the Confict of Laws, 1959 DUke L.J. 171, 176. 
However, a main virtue of Currie's approach is the probability of a more sensible result than would follow from the traditional and mechanical tests. By inquiring into the actual interests of the states involved, it becomes evident that there are few situations in which two states will have conflicting interests, even though the domestic laws of each state may differ. ${ }^{25}$ Thus, applying the law of the sole interested state will avoid unnecessary choice of law considerations where false conflicts exist. Unlike the mechanical tests that inquire, for example, only where the contract was made or the tort occurred, Currie's theory avoids the results of those cases in which laws have been applied that did not advance the interests of foreign jurisdictions and that often were contrary to the interest of the forum. ${ }^{20}$

Application of the governmental interest theory, of course, requires determining how a state's "imterest" is established. In his two intensive case studies, both dealing with dissimilar fact situations, Currie gave decisive weight to the residences of the parties. ${ }^{27}$ In Currie's illustrative example relating to laws denying married women the capacity to contract, ${ }^{28}$ he concludes that it would be absurd for a state having such laws to invalidate a contract made within its borders between a married woman and a creditor when both are residents of a foreign state that would validate the contract. ${ }^{29}$ Currie reasons that the policy of sucls a law could be intended only for the protection of resident married women, and that where two nonresidents are involved the forum state's policy in no way can be advanced by invalidating the contract. A traditional criterion such as the place of contracting is disregarded.0

Currie has provided for the possibility of factors otler than residence in the structure of a state's interest. ${ }^{31}$ In the problem liere under consideration, where there are elements involved peculiar to the law of business associations, additional factors may be decisive in establishing a state's interest. For example, a state niay have an interest in protecting or encouraging the creation of local companies, even though the particular investor involved in a given case is not a local resident. Thus, the present problem may afford the framework for an extension of Currie's theory.

25 See Currie, Married Women's Contracts: A Study in Conflict-of-Laws Method, 25 U. CHII. L. REv. 227 (1958).

26. Ibid.

27 Currie, Survival of Actions: Adjudication Versus Automation in the Conflict of Laws, 10 Stan. L. Rev. 205 (1958); Currie, Married Women's Contracts: A Study in Conflict-ofLaws Method, 25 U. CHI. L. REv. 227 (1958).

28 Currie, Married Women's Contracts: A Study in Confict-of-Laws Method, 25 U. CEr. L. REv. 227 (1958).

29 Id. at 239.

30 If the creditor is a resident, but the married woman is not, the forum does not use its own law as the rule of decision, since the forum policy is not intended to favor foreign married women over local creditors. This result raises issues involving the privileges and immunities clause, U.S. Const. art. IV, § 2. See note 91 infra. Where the married woman is a resident and the creditor is not, Currie applies tlie forum law to protect the woman in accord with forum policy, notwithstanding the interest of the foreign jurisdiction in protecting its creditor.

31 In his article, Notes on Methods and Objectives in the Confict of Laws, 1959 DuKE L.J. 171, Currie sets forth principles of general application that were derived froun more specific analysis in other articles. In so doing lie has indicated the possibility of factors other than the residences of the parties, although he has not suggested specifically what these factors might be. Moreover, he has commended Mr. Justice Traynor for continuing the search for state interest after discovering the plaintiff's local domicile. Currie, Justice Traynor and the Conflict of Laws, 13 Stan. L. Rev. 719, 778 n.236 (1961). 


\section{III}

\section{THE NEED FOR A UNIFORM RESULT}

To safegnard and promote use of the corporate form, it is generally recognized that a uniform and predictable treatment of corporations is desirable, and that a single body of law should control corporate operations as much as possible. ${ }^{32}$ The * imminent resurgence of the business trust similarly raises the need for a reasonably predictable legal environment. ${ }^{33}$ The possibility of subjecting a few beneficiaries to personal liability for the debts of a large and widely owned company, while other beneficiaries avoid liabihty, would discourage utilization of the business trust. Unfortunately, a single law suitable for uniform application is not easily ascertained or accepted, and uniformity in choice of law situations must often remain a desirable but unachieved goal. ${ }^{34}$

Probably the most obvious suggestion for achieving a uniform result in the present problem is that the law of the state of trust organization should be used to determine the liability of trust beneficiaries. ${ }^{35}$ This clroice of law rule is supported by the Tentative Draft of the Second Restatement, ${ }^{36}$ although that publication does not deal specifically with business trusts. The Restatement states that limited liability for corporate shareholders granted by the state of incorporation slould be recognized by all states, ${ }^{37}$ and then suggests that other associations should be treated the saine as corporations insofar as they have the same attributes. ${ }^{38}$ The difficulty with the Restatement position, however, is that all states clearly recognize limited liability for corporate shareholders and there is little policy conflict involved in one state looking to the law of another. Equating the business trust to the corporation to arrive at the saine choice of law rule would be to ignore the reality that all states do not give limited liability to trust investors. ${ }^{39}$

32 See generally Badr, Alten Corporations in Conflict of Laws 89 (1953); 2 Rabei, CONFLICT OF LAwS 3 (1947).

33 See 2 RaBEL, op. cit. supra note 32, at 16, 107-11.

34 See generally Currie, Married Women's Contracts: A Study in Conflict-of-Laws Method, 25 U. Cer. L. Rev. 227, 263-68 (1958).

35 A rule referring to the state of trust organization is not the only possibility. Should the trust do a substantial amount of business in more than one state, a court may be inclined to select a choice of law rule that refers to the law of the state in which the company maintains its principal place of business, or has its center of operations. See 2 RABEI, op. cit. supra note 32, at 31-45. In the interest of predictability, lowever, this rule would be somewhat less desirable than the one previously discussed, particularly in view of multistate business activities that would make it difficult to select the center of operations or principal place of business.

36 Restatentent (Second), Conflict of Laws (Tent. Draft No. 7, 1962); see Note, The Real Estate Investment Trust in Multistate Activity, 48 VA. L. Rev. 1125, 1145-46 (1962).

37 Restatedent (SeCOND), Conflict of Laws \$ 154, comment $c$ (Tent. Draft No. 7, 1962).

38 Id. at 31-32 (introductory note).

39 The Restatement, id. $\$ 154$, comment $c$, says that:

in so far as this protection is accorded them in the state of incorporation, a state... will recognize the immunity of shareholders of a foreign corporation from being sued as individuals on matters arising out of the acts or omissions of the corporation and from laving their individual property inade responsible for obligations of the corporation.

Applying this to business trusts, if the trust meets the "uitimate control" test of the state in which it is organized, see note 11 supra, then limited liability for beneficiaries should be recognized in all states. 
The use of a choice of law rule that refers to the state of trust organization would presumably be justified only by balancing the various interests and policies involved, ${ }^{40}$ and by resolving this balance in favor of such a rule. ${ }^{41}$ Since the law to be applied in using this rule invariably would be $X 1 a w,{ }^{42}$ the balance reduces to considering the interests favoring $X$ law as opposed to those favoring $Y$ law, and then determining which interests should yield for the sake of uniformity. ${ }^{43}$ On the side of $Y$ law is the interest of the $Y$ forum in regulating business within its state boundaries. $Y$ may have an interest in protecting local creditors against foreign companies that have not complied with $Y$ 's statutory controls of business associations. On $X$ 's side of the balance, the recent federal tax legislation indicates a preference for $X$ law, or at any rate for the business trust as a means for encouraging the development and widespread ownership of real estate. Business trusts now no doubt will be spurred to form and operate on a nationwide basis, and there is need to permit large numbers of investors to participate safely in such activity without receiving extraordinary treatment that frustrates their reasonable expectations. ${ }^{44}$ Furthermore, creditors dealing with large companies ${ }^{45}$ look for security in the company itself; to allow recovery from individual shareholders would be a windfall to these creditors. ${ }^{46}$ In the balance, $Y$ 's interests would seem insufficiently strong to justify holding investors individually liable in

40 Professor Currie would argue that it is not the function of the judiciary to weigh the competing interests and make a balance to determine the choice of law result. Currie, Notes on Methods and Objectives in the Conflict of Laws, 1959 DuKe L.J. 171, 176.

41 In deciding whether to seek a choice of law rule for purposes of uniformity, a distinction is ordinarily made between those problems dealing primarily with the internal affairs of a corporation and those bearing more heavily on the interests of third persons outside the corporation. See Reese \& Kaufman, The Law Governing Corporate Affairs: Choice of Law and the Impact of Full Faith and Credit, 58 Corum. L. Rev. 1118, 1120 (1958). Problems of the former type, i.e., those of the corporation, its owners, and management inter se, normally suggest a greater need for uniformity. Moreover, such problems are more suitable for uniform treatment since outside persons, and states other than that of incorporation, usually have no interest in internal corporate affairs. Where the rights of third persons, e.g., creditors, are involved, it is more difficult to justify the umiform use of a simgle law that will conflict with other laws favoring third persons. While involving to some extent the rights of third persons, the potential liability for company debts would seem legitimately to be included among the inter se rights of sharcholders. Indeed, the possibility of nonumiform and fortuitous liability of the shareholders would influence greatly their deciding whether to invest in the trust in the first place. Moreover, the realistic expectations of both trust investors and creditors would seem to establish the issue of liability as one inter se. See note 44 and text accompanying note 46 infra.

42 It is unlikely that trusts will be organized in $Y$ states.

43 The present discussion assumes that $Y$ states actually have an interest in applying their local law. It is arguable, however, that whatever $Y$ policies might be, they are not furthered by holding shareholders individually liable. See discussion in part IV, B, 1(a), following note 84 infra. If there is no interest in applying $Y$ law in a choice of law situation, then of course there is no balance to be made.

44 Considering the realities of modern investment procedures, it would appear that the typical investor assumes only that he is dealing with the company in which he is purchasing shares, and that his greatest risk is loss of his investment. This would seem to be particularly true in the case of a business trust, since there will probably be at least 100 individual investors. See note 45 infra.

45 INT. REv. CODE OF 1954, $\$ 856$ (a) (5), requires that there be at least 100 beneficial owners of the trust to qualify for the noncorporate tax treatment.

46 It may be argued, however, that a creditor in a $Y$ state dealing with a business trust knows the law of his state regarding such companies, and relies on such law. Furthermore, tort obligations of the trust may not involve the consideration of reliance by the third person. 
choice of law situations. ${ }^{47} Y$ 's interests could be furthered more effectively by direct action against the trust itself, either by ousting it from the state, making it incorporate therein, or forcing it to comply with statutory regulations directed at foreign corporations. ${ }^{48}$ When choosing between creditors who can be said to rely little on shareholder liability for their security, and shareholders who do not expect to be personally liable for obligations of their company, the latter seem more deserving of protection.

Whether $Y$ states would conclude in favor of $X$ law is the unascertainable barrier to uniformity. The possibility a $Y$ state might deem $X$ law contrary to its public policy, ${ }_{2}^{49}$ or graft other exceptions to the rule referring to the place of organization, as well as the existence of more than one cloice of law rule, ${ }^{50}$ makes the prospect of uniformity unlikely.

\section{IV}

\section{ANALYSIS}

This part of the comment considers case law in connection with Currie's theory and the rule referring to the state of organization. As explained in the introduction, the problem is considered in four different situations. Since the dearth of relevant cases dealing with business trusts results in an inconclusive analysis, cases covering the analogous fields of corporations and partnerships are also discussed.

\section{A. Situation (1)}

In this situation an $X$ trust is transacting business both in $X$ and $Y$, and a beneficiary is sued in $X$ for a liability arising from a $Y$ transaction.

\section{Governmental Interest Theory}

In applying Currie's theory, the possible circumstances unust be determined that would justify $X$ 's applying its own law to immunize the defendant-beneficiary. This determination involves an examination of $X$ 's policy, followed by an examination of its interests based on this policy.

Assuming that one policy nnderlying $X$ 's laws is to favor the formation of local business trusts as a desirable type of limited liability company, it seems reasonable to conclude that $X$ has a legitimate interest in protecting its domiciliary trusts. This interest might be considered similar to one based on a policy for the protection of resident creditors, debtors, or other persons. ${ }^{51}$ In addition, the

47 Professor Ehrenzweig, in discussing unincorporated associations, suggests that companies approaching corporate status may have shareholder hability determined by the law of the state of organization. His criterion for the requisite degree of corporateness seems to be that the association publicly record the instrument setting forth its organization and effect. See EERENZWEIG, ConfLicr of Laws 423-25 (1962). This theory would appear applicable to business trusts publicly recording the declaration of trust by which they are organized.

${ }^{48}$ See Heinphill v. Orloff, 277 U.S. 537 (1928) (discussed in note 85 infra) ; State v. United Royalty Co., 188 Kan. 443, 363 P.2d 397 (1961) (discussed in note 86 infra).

40 See Means v. Limpia Royalties, 115 S.W.2d 468 (Tex. Civ. App. 1938) (discussed at text accompanying note 93 infra); cf. Farmers' and Merchants' Nat'l Bank v. Anderson, 216 Iowa 988, 250 N.W. 214 (1933) (discussed at text accompanying note 119 infra).

50 See note 35 stupra.

E1 If the trust is treated as an entity residing or domiciled within the state, then no reason appears why the entity could not be as nucls the object of a local protective policy as an individual person. 
policy favoring business trusts may give rise to an interest transcending that of merely protecting locally created companies. An interest of $X$ qua state is furthered when investors and businesses are encouraged to bring their wealth into $X$, rather than an interest respecting only a particular individual or group within the state. The courts of $X$ may well be applying a true governmental interest in advancing the state's economy and welfare through favorable treatment of the business trust, even though this extends Currie's theory as presently expounded. ${ }^{\text {t2 }}$

When the creditor or plaintiff as well as the defendant-beneficiary both are residents of $X$, the application of the lex fori clearly is supported by Currie's writings, since the situation is virtually domestic. ${ }^{53}$ If only the beneficiary is an $X$ resident, then $X$ still has an interest in applying its own laws to protect its resident, since this presumably is a main policy underlying $X$ 's law. ${ }^{54}$ Should neither the creditor nor the beneficiary be residents of $X$, an application of the forum law still could be predicated upon the interests of protecting domiciliary trusts and of advancing the state's economy. This would be the case even though the creditor might be a local resident, since $X$ otherwise would appear to have no interest that results in denying the creditor recovery. ${ }^{.5}$

The foregoing results would follow a fortiori if the $X$ trust did not do business in $Y$. That is, if the only relations with $Y$ consisted of either of the parties being residents of that state, an $X$ court should have even less difficulty in determining to apply its own law.

If a particular $X$ trust transacted all of its business outside of $X$, this analysis may not be entirely applicable. It would become more difficult to characterize the trust as a "resident" and there would be little advancement of $X$ 's economy. While $X$ 's interest in protecting resident beneficiaries might subsist, it is possible that $X$ no longer would have an interest in protecting the trust itself., ${ }^{50}$

\section{Case Analysis}

\section{a. Business Trust Cases}

Only one business trust case las been found that is on point with situation (1). In Gutelius v. Stanbon, ${ }^{57}$ a federal district court sitting in Massachusetts held that Massachusetts law should determine the liability of a beneficiary for trust

$\mathbf{5 2}$ The term "governmental interest" as used by Currie has been criticized as inaccurately describing an interest in the protection of particular residents rather than one of the state in general. See Ehrenzweig, Choice of Law: Current Doctrine and "True Rules," 49 Carrf. I. Rev. 240 (1961). The latter type of interest, however, would appear clearly possible under Currie's theory.

53 It is possible that $Y$ law would be applicable in a contract action if the parties actually intended this and made the intention understood. Intent, however, should not be fictionally derived, e.g., from the place of contracting or from the place where the contract is to be performed. See text following note 76 infra.

54 This would be an example of Currie's theory as he has applied it explicitly, since residence is the determining factor.

55 The $X$ creditor would seem to be in no position to object to the application of his own local law, particularly where he is dealing with a local trust.

56 If, however, an $X$ court was to deny sanction to a locally created trust because of insubstantial business done within $X$, this might cause some hesitation on the part of those considering trust organization in $X$. The possibility of an $X$ court ruling adversely to an $X$ trust may thus impede the overall advancement of $X$ 's economy, and justify giving limited liability regardless of the business done in $X$.

5739 F.2d 621 (D. Mass. 1930). 
contract debts incurred in Florida transactions. ${ }^{58}$ The trust had been organized in Massachusetts. Although the court applied Massachusetts law without explaining the basis for the choice of law rule used, the result does appear consistent with that suggested by the governmental interest theory. ${ }^{59}$ The saine result would follow from the choice of law rule that refers to the place of trust organization. ${ }^{60}$

\section{b. Corporation Cases}

In Leyner Eng'r Works v. Kempner, ${ }^{61}$ defendant shareholders in a Texas corporation were sued in a federal district court in that state for corporate habilities incurred in Colorado transactions. A Colorado statute provided that shareholders became liable as partners if there was a failure to comply with statutory requirements for foreign corporations, and suit was predicated on this law. ${ }^{62}$ The court held that the hability was governed by the law of the corporation's domicile, and Texas law was applied to protect the defendants.

The Enghish case of Risdon Iron \& Locomotive Works v. Furness ${ }^{63}$ involved a provision of the California Civil Code, now repealed, that iniposed personal liability on the shareholders of all corporations, domestic or foreign, doing business in Cahifornia. ${ }^{64} \mathrm{~A}$ shareholder in an English conpany was sued in England on the basis of this California statute for his share of a conpany debt incurred while doing business in California. The memorandun of association of the company expressed the purpose to do business in "Austraha, the Umited States, and elsewhere."

58 Massachusetts, of course, is an $X$ state, Greco v. Hubbard, 252 Mass. 37, 147 N.E. 272 (1925), and personal liability for beneficiaries under Florida at that time was probable, Willey v. W. J. Hoggson Corp., 90 Fla. 343, 106 So. 408 (1925) ; see Jones, Business Trusts in Florida -Liability of Shareholders, 14 U. FIA. L. REv. 1 (1961). Gutelius was thus a case of true conflict insofar as the court actually was confronted with a choice of two different laws. This has significance for those commentators who argue that choice of law language is not entitled to much weight when the law of the forum was the same as the foreign law to which reference was made. See, e.g., Ehrenzweig, Choice of Law, Current Doctrine and "True Rules," 49 CarIF. L. Rev. 240 (1961).

50 There was no mention in Gutelius of the residences of the parties involved. A case indicating the saine result, though involving a different fact situation, is Farmers' \& Merchants' Nat' Bank v. Anderson, 216 Iowa 988, 250 N.W. 214 (1933). A business trust which was formed in Texas, a $Y$ state, incurred hability while transacting business there. A beneficiary was sued in Iowa, an $X$ state. Recognizing the conflict between Texas and Iowa laws relating to business trusts, the Iowa court held that foreign law must give way when in conflict with the public pohicy of the forum. Accordingly, the defendant was relieved of liability although he would have been held hable as a partner under Texas law. It follows a fortiori that an Iowa court wonld reach the same result if a trust is organized in Iowa.

The Farmers case also illustrates how a court may graft exceptions on a choice of law rule referring to the place of trust organization, should the forum feel that its own interests outweigh all others.

00 But see note 59 supra.

61163 Fed. 605 (C.C.S.D. Tex. 1908).

62 Cozo. Rev. Stat. ANn. \$\$ 31-10-1, -2, -5 (1953).

63 [1905] I K.B. 304, aff'd, [1906] 1 K.B. 49.

64 Cal. Stat. 1905, ch. 339, at 396 (CAI. Crv. Code $\$ 322$, repealed in 1931), provided that the hability of each stockholder of a corporation formed under the laws of any other state or territory of the United States, or of any foreign country, and doing business within Cahfornia, was the same as the liability of a stockholder of a corporation created under the constitution and laws of California. Stockholders of California corporations were proportionately liable for all the debts of the corporation, in the percentage in which they held stock in the corporation.

65 [1906] 1 K.B. at 50 . 
not be liable individually, a valid provision under English law. The court held that the defendant was not liable, primarily on the ground that there was nothing from which to derive authority to extend the slareholder liability beyond that stated in the memorandum.68

In both the Leyner and Risdon cases, the foreign law was explicit in its intended application to the shareholders of corporations that are domiciled in the forum state; nevertheless, both courts chose not to apply the foreign law. These cases are ones of true conflict under Currie's theory, ${ }^{67}$ and strongly support the result suggested by that theory. ${ }^{68}$ The reasoning of the Risdon case, which looked to the authority given by the shareholder to the corporation, also supports the proposition that the issue of shareholder hability comes under the internal affairs of the corporation, and that this issue is to be decided by the law of the corporate domicile.

An $X$ forum under some circumstances may hold a beneficiary subject to trust liabilities incurred in $Y$. In Tovele $v$. Beistle, ${ }^{69}$ the facts were substantially the same as in the Leyner case. The defendants, shareholders in an Indiana corporation, were sued in Indiana on the basis of liability arising out of corporate activities in Tennessee. Tennessee law, similar to that of Colorado, made shareholders of noncomplying foreign corporations individually liable. The Indiana court held that "the mere fact alone of ownership of the common capital stock ... in the . . . corporation organized to do business in Indiana and not in Tennessee is not sufficient to hold the appellees responsible. ..."70 The court implied, however, that the result would have been different had the corporation been expressly authorized to do business in states outside Indiana, indicating that in the latter situation hability could be predicated upon the shareholder's consent to be bound by the laws of the jurisdiction in which business is transacted. ${ }^{71}$

In Thomas v. Matthiessen, ${ }^{72}$ the Supreme Court of the United States was confronted with the same California code provision that was involved in the Risdon case. ${ }^{73}$ The facts, however, differed; an Arizona corporation incurred a liability while doimg business in California, and a diversity suit was brought against a shareholder in a New York federal court on the basis of the California

${ }^{66}$ Id. at 56.

${ }^{67}$ See text accompanying note 25 supra.

68 Another case indicating the result of Risdon and Leyner is Hutchins v. New England Coal Mining Co., 86 Mass. (4 Allen) 580 (1862). The shareholders of a Massachusetts corporation were sued in Massachusetts on the basis of an individual habihity imposed by forum corporation statutes. The liability, however, was incurred in transactions in Rhode Island, and the defendants pleaded that under Rhode Island law they should not be held liable. The court held the defendants liable and stated in general terms that the duties created by the state of incorporation could not be eluded by the laws of other states. Id. at 582-83. This decision indicates that the forum would uphold its own laws regarding shareholder immunity, rather than liability, notwithstanding foreign laws to the contrary.

For an extensive criticism of the Risdon and Leyner decisions see Hohfeld, Nature of Stockholders Individual Liability for Corporation Debts, 9 CoLUM. L. REv. 285 (1909); Hohfeld, The Individual Liabiilty of Stockholders and the Conflict of Laws, 9 CoLux. L. REv. 492 (1909), 10 Colvas. L. Rev. 283, 520 (1910).

6897 Ind. App. 241,186 N.E. 344 (1933), Note, 9 IND. L.J. 316 (1934).

7097 Ind. App. at 247,186 N.E. at 346.

71 Ibid.; cf. Cunnyngham v. Shelby, 136 Tenn. 176, 188 S.W. 1147 (1916).

72232 U.S. 221 (1914).

73 See text accompanying notes 63-65 supra. 
statute. Reversing the decisions of both lower federal courts, ${ }^{74}$ and contrary to a prior New York decision, ${ }^{75}$ the Supreme Court held the shareholder hable. This was not a constitutional decision under the full faith and credit clause, ${ }^{76}$ and the Court did not rely on choice of law considerations. Rather, it was influenced by the facts that the defendant was instrumental in organizing the corporation, and had expressed in writing prior to its final incorporation the intent to have the corporation acquire land and do business in California. The Court thus appears to have held that the defendant acquired his interest in the corporation under an implied consent to be bound by California law with respect to corporate business transacted within California.

It should be noted that New York in the Thomas case was really not an interested fornm, as was England in the Risdon case, or as Arizona would have been if this litigation were conducted there. However, Thomas, although more in point with situation (4), ${ }^{77}$ is important here in that it gave little consideration to the conflict of laws problem, focusing instead on the investor's implied consent to be bound. Thomas, similarly to Towle v. Beistle, ${ }^{78}$ suggests that an $X$ court sliould determine whether the shareholder agreed or consented to be bound by foreign laws.

Thomas does not specify the general circumstances in which an investor will be considered to have so consented. Although the facts relating to the particular defendant in Thomas may have justified the decision, the situation would seem to be different where an innocent investor simply buys into a company without reading its charter or papers of formation, or participating in its creation or management. Moreover, as noted above, ${ }^{79}$ the typical investor in a large company rarely expects to be made responsible for its operation. To imply a consent on the part of the investor to be bound by the laws of foreign states in such circumstances would seem to be fictitious. ${ }^{80}$ Thus it appears that the aspect of shareholder innocence would distinguish the Risdon from the Thomas case.

The possibility of imposing shareholder liability in situation (1) under a consent theory is not necessarily at odds with the result suggested by the governmental interest theory. While the forum may have a policy of affording investor immunity, the forum would not have a legitimate interest in applying this policy where the trust and investors truly agreed to give up the advantage of immunity. The cases of Torole v. Beistle and Thomas v. Matthiessen can be taken as standing only for the proposition that an investor may agree to relinquish his immumity for the sake of doing busmess in a foreign jurisdiction. If, however, a court merely ascribes a fictional consent on the part of the investor, then the case becomes one in which the forum displaces its own pohicy in favor of that of a foreign state.

The Towle and Thomas decisions also can be reconciled with the choice of law mle that refers to the law of the state of incorporation. Simce this rule is premised on the need for stabilizing the inter se relationships of the company and

74170 Fed. 362 (C.C.S.D.N.Y. 1909); 192 Fed. 495 (2d Cir. 1911).

75 Coulter Dry Goods Co. v. Rosenbaum, 74 Misc. 579, 134 N.Y. Supp. 487 (1911).

76 Cf. Broderick v. Rosner, 294 U.S. 629 (1935).

77 See discussion in part IV, $\mathrm{D}$, following note 132 infra.

7897 Ind. App. 241, 186 N.E. 344 (1933).

79 See note 44 supra and accompanying text.

80 See Note, 12 Colum. L. Rev. 450 (1912); Note, 18 HARv. L. Rev, 452 (1905); cf. Note, 44 HARV. L. REV. 615 (1931). 
its owners, an actual consent to be bound by foreign law should be upheld no less strongly than the expectation not to relinquish individual immunity.

\section{c. Partnership Cases}

Articles of limited partnership were filed in Maryland by the defendant and others in Gilman Paint \& Varnish Co. v. Legum. ${ }^{81}$ Plaintiff shipped goods from Tennessee to the partnership in Georgia, the primary place of partnership business. Contrary to plaintiff's argument for application of Georgia law, the Maryland court held that the partners' liability must be determined according to Maryland law.

In Barrozes v. Dorens \& $\mathrm{Co}_{0}{ }^{82}$ a limited partnership was formed under the laws of Cuba, and a general partner in the firm negotiated a contract in New York. Suit was brought in Rhode Island against a limited partner on the basis of the firm's contract liability. The court stated in a dictum that the authority and power of a general partner to bind a special partner is governed by the law of $\mathrm{Cuba}$, the place where the authority was created. From this it follows that Rhode Island, if it was the place of partnership organization, would have applied its own law to determine the liability of a limited partner. ${ }^{83}$

Both the Barrowes and Gilman cases strongly support the rule that a forum should look to the law of the place where the company is created. Although the two cases also are consistent with the result under the governmental interest theory, it is not clear from the opinions whether these cases involved true conflicts. Neither case discusses the substance of any law other than that actually applied. ${ }^{84}$

\section{B. Situation (2)}

In this situation an $X$ trust is doing business within $Y$, and a beneficiary of the trust is sued in a $Y$ court on the basis of a trust liability. Only the location of the forum distingnishes situation (2) from (1).

\section{Governmental Interest Theory}

\section{a. Foreign Business Trust Deemed to Be Foreign Corporation}

Arguably, the circumstances in which $Y$ could advance its policy relating to business trusts are irrelevant with regard to situation (2). Instead, the important criteria may be $Y$ 's policies and laws concerning foreign corporations doing business in $Y$, and the effect of noncomphance with such laws.

When $X$ permits business trusts to enjoy corporate advantages without complying with corporation statutes, this properly concerns only the policies of $X$. However, even though an $X$ trust may avoid $X$ corporation laws, it cannot circumvent similar laws of $Y$. When transacting business in $Y$, business trusts may be required to comply with laws regnlating the admission of foreign corporations. ${ }^{85}$

81197 Md. 665, 80 A.2d 906 (1951).

829 R.I. 446, 11 Am. Rep. 283 (1870).

83 In this case, the defendant was found to have held himself out as a general partner, and thus the court held him liable.

84 Cf. First Nat'l Bank v. Hall, 150 Pa. 466, 24 Atl, 665 (1892).

85 In Hemphill v. Orloff, 277 U.S. 537 (1928), it was held by the Supreme Court of the United States that, as a prerequisite to doing business within Michigan, a business trust formed in Massachusetts could be made to comply with Michigan laws regulating the admission of foreign corporations. A trustee acting in hchalf of the business trust could not avail himself of 
$Y$ policy lias determined that forum statutes must be met to provide limited liability for slareholders in a wholly domestic situation. When dealing with a foreign business trust, however, $Y$ policy should be unconcerned with whether the trust has complied with the corporation laws of $X$, the state of trust organization. Even a foreign corporation lawfully organized under the laws of its domicile is not assured the riglit of transacting business within $Y$; it must also comply with $Y$ laws regulating foreign corporations. Y's interests slould be concerned with regulating foreign companies regardless of the circumstances surrounding formation within their domicile state, and with seeing that foreign companies purporting to lave advantages of domestic statutory companies comply with $Y$ laws intended for their regnlation.

Thus, liability of beneficiaries in situation (2) should depend on the forum policy regarding noncomplying foreigu corporations. ${ }^{86}$ Since $Y$ is unconcerned with the manner in whicli a foreign company is organized in its domicile, ${ }^{87} \mathrm{Y}$ has no reason to differentiate between foreign corporations and foreign trusts when either fails to comply with $Y$ regnlating laws. If the forum law would not subject the shareholders of a noncomplying foreign corporation to individual liability, then the forum should not impose such liability on investors in $X$ business trusts. ${ }^{88}$

the privileges and immunities clause of the Constitution in order to do business within Michigan as an individual citizen. Id. at 550. Several other states have recognized their right to admit foreign business trusts only upon the condition of comphance with various local regulatory laws. See, e.g., Wagner v. Kelso, 195 Iowa 959, 193 N.W. 1 (1923) (Blue Sky regulation); Pennicard v. Coe, 124 Ore. 423, 263 Pac. 920 (1928) (Blue Sky regulation); State ex rel. Colvin v. Paine, 137 Wash. 566, 243 Pac. 2, aff'd on rehearing, 247 Pac. 476 (1926) (subjected foreign trust to general corporate regulatory laws; see note 4 supra).

86 It is clearly proper to treat a foreign business trust as a corporation. See Hemphill v. Orloff, 277 U.S. 537 (1928). In the recent Kansas case of State v. United Royalty Co., 188 Kan. 443,363 P.2d 397 (1961), a court in a $Y$ forum was willing to analogize foreign busimess trusts to corporations. The defendant was a business trust lawfully organized under the statutes of Oklahoma, see Oria. Stat. Ans. tit. 60, $\$ 174$ (1949), but doing business in Kansas without having coinphed with Kansas corporation law. In an equity action brought by the state to prevent the defendant from doing business in Kansas, the court held that the trust would be permitted to comply with Kansas law. It should be noted that Kansas no longer follows a $Y$ policy, but, apparently infiuenced by the federal tax legislation, has enacted laws favorable to the business trust. Kan. Gen. Stat. ANN. § 17-2028 (Supp. 1961). The court in State v. United Royalty Co., however, made no mention of this enactment.

Other cases also suggest treating foreign companies as a corporation. In Hill-Davis $\mathrm{Co} . \mathrm{v}$. Atwell, 215 Cal. 444, 10 P.2d 463 (1932), the California court treated a limited partnership formed in Michigan as a corporation for the purpose of determining the company's power to hold land in its own name. That Michigan designated the company as a partnership was deemed mconclusive with regard to its status in California. See also Liverpool Ins. Co. v. Massachusetts, 77 U.S. (10 Wall.) 566 (1870) ; Keystone Bank v. Donnelly, 196 Fed. 832 (E.D.Pa. 1912); Textile Properties v. M. J. Whittall Associates, Ltd., 157 Misc. 108, 282 N.Y. Supp. 17 (1934); cf. American Ry. Express Co. v. Asher, 218 Ky. 172, 291 S.W. 21 (1927).

87 This assumes that the company is properly organized under the laws of its domicile state. If an $X$ trust did not meet the "ultimate control" test, then there would be little reason for a $Y$ court to afford limited liability.

88 In some instances noncompliance has been deemed to give the forun government cause to complain, in the form of an action brought by the state to prevent the company from doing business. See, e.g., State ex rel. Colvin v. Paine, 137 Wash. 566, 243 Pac. 2, aff'd on rehearing, 247 Pac. 476 (1926); cf. State v. United Royalty Co., 188 Kan. 443, 363 P.2d 397 (1961) (discussed in note 86 supra). In other cases the forum has denied the noncomplying business the right to enter into valid contracts. See, e.g., Hemphill v. Orloff, 277 U.S. 537 (1928). And finally, some states subject the shareholders of a nonconplying corporation to full individual liability for corporate transactions conducted illegally within the forum state. See Empire Mills 


\section{b. Trust Lare of $Y$ Applied in Situation (2)}

It is, of course, possible that a $Y$ court will not analogize the foreign business trust to a foreign corporation for purposes of granting investor immunity. The policy against business trusts may be deemed more severe than that against foreign corporations not complying with $Y$ law. In this event, the circumstances must be determined in which a $Y$ forum would have a legitimate interest in applying its business trust law to hold the defendant-beneficiary liable. ${ }^{80}$

Currie's criterion, using the residences of the parties, indicates that one purpose of $Y$ 's business trust law is to protect creditors who reside in $Y$, through control and regulation of trusts doing business in $Y$. A similar interest would appear to exist if the creditor, although not personally a resident of $Y$, does his business in $Y$. Thus, for those situations in which the plaintiff or creditor is a $Y$ resident or does business in $Y$, the forum has a legitimate interest in applying its own law, ${ }^{00}$ and the shareholder may be held liable.

Should the litigation involve a creditor not residing or doing business in $Y$, it would seem that under the governmental interest theory the $Y$ forum would not have a sufficient interest to hold the beneficiary liable. ${ }^{01}$ If, in addition, the beneficiary was a $Y$ resident, any possible interest in protecting the beneficiary would strengthen the decision not to hold him liable. For example, if the forum's position against business trusts partly is derived from the feeling that business trust beneficiaries are not protected adequately and lose control over their investment, then it would not further such a policy to impose individual liability on the beneficiary.

If the analysis relating to noncomplying foreign corporations set forth under

v. Alston Grocery Co., 4 Tex. Ct. App. Dec. Civ. 346, 15 S.W. 505 (1891) ; cf. Towle v. Beistle, 97 Ind. App. 241, 186 N.E. 344 (1933); Leyner Eng'r Works v. Kempner, 163 Fed. 605 (C.C.S.D. Tex. 1908).

A potential problem confronts an $X$ business trust seeking to do business in a $Y$ state in actually complying with $Y$ regulations directed at foreign corporations without losing its status under $X$ law. While little difficulty would be presented by $Y$ requirements to file reports or pay taxes, $X$ limitations on the business trust could make it unable to comply with other types of $Y$ regulations. For example, $\boldsymbol{Y}$ might require that investors in limited hability companies be allowed to liold annual meetings, to have certain voting rights, and to be afforded other protective measures designed to give the investor in effect "ultimate control" over the company. Sec note 11 supra and accompanying text. In such circumstances, the trustees obviously must take care to avoid unaking sucl fundamental structural changes that the trust would no longer be able to retain limited liability advantages withm its domicile state.

89 This inquiry also would be relevant if a $Y$ state liad laws holding personally liable the sharcholders in noncomplying foreign corporations, but no $Y$ state appears to have such laws. Cf. Coro. Rev. Stat. ANv. $\S \S 31-10-1,-2,-5$ (1953) (an $X$ jurisdiction).

90 It is relevant to consider whether the particular liability actually arose from business being done within $Y$. If the liability stems from business transacted solely outside $Y$, then the fact that other business is being done within $Y$ is the only factor distinguishing this situation from situation (3). However, the presence of any business activities within $Y$ should give the $Y$ forum a legitimate interest in regulating and controlling such activities, regardless of where the particular liability arose. This interest may be somewhat similar to that necessary for the forum to gain jurisdiction over a foreign company, with the minimum contacts providing the necessary connection. See Note, Developments in the Law: State Court Jurisdiction, 73 Harv. L. REv. 909, 930-32 (1960).

91 Problems involving the privileges and immunities clause, U.S. Consr. art. IV, $\S 2$, are raised when the creditor is not a $Y$ resident. Curric would answer that the nonresident creditor may be treated the same as the $Y$ creditor only if the nonresident would be so treated in his own state. Currie, Married Women's Contracts: A Study in Conflict-of-Laws Method, 25 U. C프. L. REv. 227, 255-57 (1958). Thus, unless the nonresident creditor resides in a state also laving a $Y$ policy, Currie would not find it necessary in this situation for $Y$ to apply its own law. 
part $a$ above ${ }^{92}$ is not accepted, it is seen that, depending on the forum in which suit is brought, Currie's theory im situation (2) could lead to a result different from that in situation (1), if the $Y$ forum has an interest in protecting the creditor. In (1), the beneficiary would not be hable; in (2) he would.

\section{Case Analysis}

\section{a. Business Trust Cases}

The case of Means $v$. Limpia Royalties ${ }^{93}$ explicitly holds that forum law applies in situation (2). Plaintiff bought shares in an Oklahoma trust in exchange for his Texas land, and then sued in Texas for rescission of the sale. Plaintiff alleged that lie was to be afforded limited hability, but that under Texas law this was not possible. The court granted the rescission, holding that Oklahoma law does not operate to extend inmunity to beneficiaries from liabilities growing out of Texas transactions. The Means decision may support the result suggested for situation (2) by the governmental interest theory. Although there appears to have been no relevant statute, two cases indicate that shareholders of foreign corporations would have been held liable individually for failure to comply witl Texas law. ${ }^{94}$ Unfortunately, however, Means was silent as to the residence of the plaintiff, and unless he resided in Texas the lolding would not support the governmental interest analysis. ${ }^{05}$ Means clearly is opposed to a choice of law rule that refers to the place of trust organization.

A second case applying forum law is McClaren v. Dawes Elec. Sign $\mathcal{E}$ Mfg. Co ${ }^{90}$ In this case a Massachusetts trust purchased goods in Indiana, where a trust beneficiary was sued. Although the court found no previous Indiana law relating to business trusts and that such trusts were good in Massachusetts, it nevertheless refused to look to Massachusetts law. The court said that the forum statutes relating to corporations could not be evaded; the beneficiaries were held hable as partners. Apparently there was no Indiana law to indicate a policy of holding individually liable the shareholders in noncomplying foreign corporations. Thus the McClaren case seems to have discriminated against a foreign trust as compared to a foreign corporation. However, the facts of the case imply that the plaintiff was an Indiana resident; consequently the case does support the version of the governmental interest theory result considered apart from the analysis regarding noncomplying corporations. ${ }^{97}$

92 See discussion in part IV, B, 1(a), following note 84 supra.

03115 S.W.2d 468 (Tex. Civ. App. 1938).

94 Empire Mills v. Alston Grocery Co., 4 Tex. Ct. App. Dec. Civ. 346, 15 S.W. 505 (1891); A. Leschen \& Sons Rope Co. v. Moser, 159 S.W. 1019 (Tex. Civ. App. 1913) (dictum); cf. Tex. Bus. CORP. ACT $\$ 8.18$ (1955).

95 See discussion in part IV, $\mathrm{B}, 1$ (b), following note 84 supra.

9686 Ind. App. 196, 156 N.E. 584 (1927). A case that may indicate a different choice of law rule is Marchulonis v. Adams, 97 W. Va. 517, 125 S.E. 340 (1924). Here a Massachusetts trust incurred tort liability while transacting business in West Virginia. The law of the place of trust organization, Massachusetts, was held to govern the liability of a beneficiary sued in West Virginia. However, the opinion indicates that the law of West Virginia may not have conflicted with that of Massachusetts; the possibility that the lolding was in accord with forum law detracts from the court's choice of law language. Furthermore, in applying Massachusetts law, the trust was found not to have met the ultimate control requirement and the defendant was held liable.

97 See discussion in part IV, B, I(b), following note 88 supra. 


\section{b. Corporation Cases}

In Stephenson v. Dodson, ${ }^{98}$ personal liability of a shareholder in a foreign corporation was sought in Pennsylvania because of the corporation's doing business in Pennsylvania without permission. The court exonerated the defendant, noting that there was no statute imposing individual liability on shareholders because the foreign corporation failed to register. Noncompliance with forum statutes was held not to subject shareholders of foreign companies to personal liability in the absence of forum law to that effect.90

Pinney v. Nelson ${ }^{100}$ involved the same Cahfornia statute ${ }^{101}$ that was involved in Thomas v. Matthiessen ${ }^{102}$ and Risdon Iron \& Locomotive Works v. Furness. ${ }^{103}$ In Pinney, a California resident owning stock in a Colorado corporation was sued in a California court under the statute and was held liable. The Supreme Court of the United States upheld the constitutionality of the statute and affirmed the decision. The Court stated that the defendant's contract witl his corporation was made in Colorado and that generally the law of the place of contracting controls the effect of the contract. But upon consideration of the corporation's charter, which specified a purpose to do substantial business in California, the Court concluded that the defendant had in fact contracted with reference to the law of California and was presumed to know the provisions thereof. A subsequent California decision ${ }^{104}$ held stockholders in foreign corporations liable in the absence of charter provisions similar to the one involved in Pinney. In these two cases, the statutory mandate to the forum court was clear in its intention to hold the shareholders liable. The governmental interest theory is nevertheless supported to the extent that the forum law was upheld when the forum's interest was established, despite any conflicting foreign interest. ${ }^{105}$

\section{c. Partnership Cases}

In King v. Sarria ${ }^{106}$ a special partner in a Cuban limited partnership was sued in New York on the basis of a liability incurred by the firm on a contract with a New York creditor. Although the court stated that the contract with the creditor could be construed under forum law, it construed the partnership agreement according to Cuban law and permitted the defendant to enjoy limited liability.

A recent Tennessee decision similarly displaced the forum law. In Spencer Kel-

0836 Pa. Super. 343 (1908). See Beal v. Childress, 92 Kan. 109, 139 Pac. 1198 (1914);

Merrick v. Van Santvoord, 34 N.Y. 208 (1866); Bank v. Hall, 35 Ohio St. 158 (1878).

${ }^{98}$ See text accompanying note 88 supra.

100183 U.S. 144 (1901).

101 See note 64 supra.

102232 U.S. 221 (1914).

103 [1906] 1 K.B. 49.

104 Provident Gold Mining Co. v. Haynes, 173 Cal. 44, 159 Pac. 155 (1916); cf. Thomas v. Wentworth Hotel Co., 158 Cal. 275, 110 Pac. 942 (1910); Peck v. Noee, 154 Cal. 351, 97 Pac. 865 (1908).

105 While the Tentative Draft of the Restatement states the general rule that shareholder limited liability provided by incorporation in one state should be upheld in all states, REsTATEMENT (SECOND), ConfuTct of LAws \$154, comment $c$ (Tent. Draft No. 7, 1962) (see note 39 supra), an exception provides that legislation by one state can impose hability on a shareholder of a foreign corporation for corporate acts done withm the state. Id. $\$ 186 a$. Whether courts in other states look to such legislation is said to depend on the choice of law rules of such other states. $I d . \S 186 \mathrm{a}$, comment $a$.

10669 N.Y. 24 (1877). Cf. Bullock v. Caird, L.R. 10 Q.B. 276 (1875). 
logg \& Sons v. Lobban, ${ }^{107}$ the defendant was a partner in a Louisiana partnership who was sued in Tennessee for a partnership liability arising at least in part from Tennessee transactions. The defendant contended that, under Louisiana partnership law, the partners could not be lield liable individually until liability was established by a judgment against the partnership as an entity. The court used Louisiana law for the rule of decision, and the suit was dismissed.

In Smith v. Warden, ${ }^{108}$ the defendants were himited partners in a Pennsylvania partnership that did business in Missouri. The plaintiff sustained personal injuries in Missouri. A Missouri court permitted recovery because of the defendants' failure to comply with Pennsylvania requirements for a limited partnership. ${ }^{109}$

The language in each of these three cases indicates that the forum's choice of law rule was to look to the place of partnership organization to determine the liability of the partners. ${ }^{110}$ With regard to the governmental interest theory, the interest of Tennessee in the Lobban case may well have been sufficiently insignificant to justify the court's displacing the forum law. The plaintiff was not domiciled in Tennessee nor did he regularly do business there. ${ }^{111}$ In King the New York forum looked to foreign law notwithstanding the plaintiff's being a New York resident. However, although the court did not discuss the fact, limited partnerships at that time could be formed under New York law; ${ }^{112}$ therefore, New York policy actually did not conflict with that of Cuba. ${ }^{113} \mathrm{In}$ Smith, the plaintiff resided in Missouri, which could have given the forum a sufficient interest to use its own law. But, as in the King case, it appears that Missouri law was not adverse to forming limited partnerships, and there was no conflict of interest with Pennsylvania.

\section{Situation (3)}

In this situation the $X$ trust transacts no business in $Y$, but a beneficiary is sued in $Y$.

\section{Governmental Interest Theory}

To hold the beneficiary hable would not appear to advance any of the forum's policies in this situation. Even though the creditor involved may be a $Y$ resident, $Y$ 's interest in protecting him must be related to the regulation and control of business trusts. Since in this situation the $X$ trust is transacting its business entirely outside $Y$ boundaries, there can be no assertion that the trust is circumventing $Y$ regulation or taxation. ${ }^{114} \mathrm{It}$ would seem unreasonable for $Y$ to impose its policies upon a completely foreign company with which a resident creditor chose to do busmess.

107204 Tenn. 79, 315 S.W.2d 514 (1958).

10886 Mo. 382 (1885).

109 See note 87 supra.

110 It has been suggested that treating the limited partnership according to the law of its state of organization is justified if the partnership pubbcly records a document setting forth its organization and effect. See note 47 supra.

111 A conflict between the laws of plaintiff's domicile and Louisiana could place the Lobban case in situation (4). See discussion in part IV, D, following note 132 infra.

112 See Van Ingen v. Whitman, 62 N.Y. 513 (1875); cf. Manhattan Co. v. Laimbeer, 108 N.Y. 578, 15 N.E. 712 (1888). supra.

113 Cf. Marchulonis v. Adams, 97 W. Va. 517, 125 S.E. 340 (1924), discussed in note 96

114 This would raise a due process problem of whether a state could regulate or tax a corporation not doing business within its borders. 
A policy against divesting investors of control over their investments ${ }^{115}$ would seem clearly to exist for the purpose of protecting investors. But $Y$ has no power to advance this policy by imposing restrictions on the trust for the investors' benefit, and it would be inconsistent with a policy of protecting investors to hold them personally hable because of their investments im a foreign business.

If the foreign trust is selling shares to investors in $Y$, it then becomes relevant to inquire whether such sales constitute "doing business" within $Y$. If the trust is considered to be transacting business in $Y$, the situation is more properly categorized under situation (2). ${ }^{116}$ A $Y$ state has held, however, that selling shares in a business trust does not constitute "doing business"; ${ }^{117}$ the foreign trust was allowed to conduct such sales despite noncompliance with statutory provisions regulating the sale of shares by companies doing business within the state. ${ }^{118}$

\section{Case Analysis}

\section{a. Business Trust Cases}

No cases have been found directly on point in this situation. In Farmers' $\mathcal{\&}$ Merchants' Nat'l Bank v. Anderson, ${ }^{119}$ an $X$ court exonerated a trust beneficiary notwithstanding the fact that the trust had been formed and liability incurred in a $Y$ state. There appeared to be no trust activity in the $X$ state. By reasoning conversely from this decision a $Y$ forum could hold a beneficiary liable in situation (3). Just as the $X$ court in Farmers' applied its law to a $Y$ trust, a $Y$ court could apply its law to an $X$ trust. The Farmers' decision has been criticized for disregarding cases enforcing the statutory liability of shareholders in foreign corporations where such liability is imposed by the law of the corporate domicile. ${ }^{120}$ Furthermore, the slight connection of the forum with the transactions in which liability was incurred weighed against the defendant's defense of forum public policy. ${ }^{121}$

In Dunning v. Gibbs, ${ }^{122}$ a trust was organized and transacted business in Texas, then a $Y$ state. ${ }^{123}$ A trust beneficiary was sued in Kentucky, also a $Y$ state, ${ }^{124}$ for a trust liability incurred in Texas. The court stated that the beneficiary's liability was to be determined by the law of the place of the trust's organi-

115 See note 21 supra.

116 See note 90 supra and discussion in part IV, B, following note 84 supra.

117 Home Lumber Co. v. Hopkins, 107 Kan. 153, 190 Pac. 601 (1920). Kansas no longer follows a $Y$ policy. See note 5 supra.

118 A contrary result may have obtained in Texas until it recently abolished its $Y$ policy. A "single act" statute, Tex Rev. Crv. Srat. art. 2031b (Supp. 1959), purports to give jurisdiction to Texas courts by constructive service on a nonresident party who makes a contract with a Texas resident to be performed in whole or part in Texas. The making of such a contract is deemed to he "doing business" in Texas, and would appear to include the salc of trust shares to Texas residents.

119216 Iowa 988, 250 N.W. 214 (1933).

120 Note, 47 Harv. L. REv. 526 (1934). See also Flash v. Conn, 109 U.S. 371 (1883).

121 Note, 47 HaRv. L. REv. 526, 527 (1934). This position is consistent with the governmental interest theory, since advancing forum policy really is not possible if the forum has not a sufficient interest in the litigation.

$122213 \mathrm{Ky} .81,280$ S.W. 483 (1926).

123 Thoinpson v. Schmitt, 115 Tex. 53, 274 S.W. 554 (1925). Texas no longer follows a $Y$ pohicy. See note 5 supra.

124 Ing v. Liberty Nat'l Bank, 216 Ky. 467, 287 S.W. 960 (1926). 
zation. The foreign law, however, had not been pleaded so the court assumed that the foreign common law applied and that it was the same as that of the forum. Applying its own law then, the Kentucky court decided that since the plaintiff himself formerly had been an investor in the trust he knew of the provisions in the trust instrument providing for investor immunity. Consequently, the court held that the plaintiff was in no position to assert partnership liability against other beneficiaries. While both Kentucky and Texas basically adhere to $Y$ policies, Texas has leld that notice of the trust provisions regarding limitation of investor habihty is not sufficient to preclude recovery against a beneficiary. ${ }^{125}$ Thus, in a sense the case involved the choice of two different laws. But, while the court's language regarding reference to the laws of Texas would support displacing forum law in situation (3), this authority is questionable since the holding ultimately rested upon application of the forum's own law.

\section{b. Corporation Cases}

In both Kaiser v. Lawrence Sav. Bank ${ }^{126}$ and Jessup v. Carnegie, ${ }^{127}$ a shareholder in a foreign corporation was sued for individual liability on the ground that corporate status was not achieved under the laws of the corporate domicile. Witlout discussing forum law or corporate relations with the forum, both courts applied the standards of the corporate domicile to determine whether de facto corporations had been formed. ${ }^{128}$

A contrary result is indicated in Paper Prods. Co. v. Doggrell. ${ }^{129}$ The defendant was one of three shareholders in an Arkansas corporation who was sued in Tennessee for debts incurred by the corporation while transacting business in Arkansas. An Arkansas statute ${ }^{130}$ provides that corporate existence begins upon filing the charter with the secretary of state. Arkansas cases had established that shareholders would be held individually liable when the cliarter was not filed with both the secretary of state and the county clerk in accordance witl statutory requirements. Here the charter had not been filed with the county clerk, and another one of the three shareholders had been held liable in a separate suit brought in Arkansas. Nevertheless, the Temiessee Supreme Court refused to hold the defendant liable. Its decision was based on two separate lines of reasoning, the strongest one probably being that the Arkansas statute, as construed by its courts, was penal and need not be enforced in Tennessee. ${ }^{131}$ Much attention also was given to the argument that, under Tennessee law, shareholders in a de facto

125 Thompson v. Schmitt, 115 Tex. 53, 274 S.W. 554 (1925).

12056 Iowa 104, 8 N.W. 772 (1881).

12780 N.Y. 441 (1880).

128 In Kaiser, it is clear from the opinion that the liability was imcurred in the state of corporate domicile. The relation of the forum to the corporate liability was not stated explicitly in the Jessup opinion, but the court noted without further discussion that the corporation was organized to do business within its domicile state, and it appears probable that the corporate transactions and liability transpired in the domicile state. In Kaiser the Iowa court found the defendant liable under Kansas law, and in Jessup the defendant was exonerated by the New York court applying Iowa law.

129195 Tenn. 581, 261 S.W.2d 127 (1953). In the companion case of Doggrell v. Great So. Box Co., 208 F.2d 310 (6th Cir. 1953), the court on rehearing reversed its earlier decision, 206 F.2d 671 (6th Cir. 1953), and followed the Tennessee Supreme Court under the doctrine of Erie R.R. v. Tompkins, 304 U.S. 64 (1938).

130 ARK. STAT. ANN. § 64-103 (1957).

131195 Tenn. at 590, 261 S.W.2d at 131. 
corporation cannot be subjected to individual liability. Referring to the Arkansas statute, the court noted that corporate "existence" had begun, and held it to be against public policy to impose liability on the defendant when de facto status would be achieved under Tennessee law.

While the Doggrell decision partly was based on the idea that the Arkansas statute was penal, ${ }^{132}$ it does not appear consistent with the governmental interest theory for the Tennessee court to have resorted to forum law on the basis of its policy interest. Perhaps Tennessee has an interest in protecting its residents against harsh rules of foreign jurisdictions, but this interest seems tenuous when a resident, as here, organizes and invests in a foreign corporation. It appears to be a windfall to the defendant if he can seek incorporation under Arkansas law yet fall back on Tennessee law to avoid habilities incurred while transacting business in Arkansas. While it may be Tennessee policy to afford immunity to shareholders in domestic de facto corporations, this policy is not advanced by applying it to foreign corporations not doing business in Tennessee.

\section{Situation (4)}

In this situation suit is brought in forum $Z$, which has no interest in the litigation other than its jurisdiction over the defendant-beneficiary. The forum is confronted with the choice of applying the laws of either $X$, the place of trust organization, or $Y$, the place where the trust incurred the liability. If, as discussed with regard to situation (2), it appears that $Y$ actually has no interest in applying its trust laws, then under Currie's theory $Z$ should look to the laws of $X$, the only jurisdiction having an interest in the litigation. If, however, $Y$ does appear to have an interest, as might be the case if the creditor was a $Y$ resident, ${ }^{183}$ then the governnental interest theory admittedly offers no solution. ${ }^{134}$ Professor Currie contends that it is not the function of the judiciary to weigh the interests of the respective states. ${ }^{135}$ This, of course, is of little solace to the $Z$ court faced with the necessity of deciding the case one way or the other. Further difficulty is presented the $Z$ forum in determining initially the relevant policy of $Y$ to be considered. That is, the $Z$ court must decide whether $Y$ 's actual interest is that relating to noncomplying foreign businesses, ${ }^{136}$ or whether $Y$ 's policy against business trusts outweighs any other consideration. ${ }^{137}$

In Thomas v. Matthiessen ${ }^{138}$ a New York federal court referred to what may be considered $Y$ law to hold the defendant shareholder personally liable. That decision, however, apparently rested on the theory that the defendant had agreed or consented to be bound by the laws of the $Y$ state in which the corporation did business.

132 See Huntington v. Attril, 146 U.S. 657 (1892). The rule that "penal" laws of foreign states need not be referred to is not unifornily accepted. See Dean, Conflict of Laws, 1954 Antulal Survey of American Law, 30 N.Y.U.L. REv. 33, 40 (1955).

133 See text acconpanying note 90 supra.

134 Although Currie has considered that $Z$ might apply the law of $X$ or $Y$ by using the one conforming to $Z \mathrm{law}$, he discards such a solution because of its arbitrary nature. Currie, Married Women's Contracts: A Study in Conflict-of-Lawes Method, 25 U. CHr. L. Rev. 227, 262-63 (1958).

135 Currie, Notes on Methods and Objectives in the Conflict of Laws, 1959 Duke L.J. $171,176$.

138 See discussion in part IV, B, 1(a), following note 84 supra.

137 See discussion in part IV, B, 1(b), following note 88 supra.

188 See note 72 supra. 
Barrowes v. Downs \& Co. ${ }^{139}$ is the only other case found that falls into the category of situation (4). While the language of the court clearly indicates a choice of law rule that involves looking to the place of partnership organization to determine a partner's liability, the opinion does not discuss any conflicting laws, and it appears that the other interested state had laws not opposed to those of the place of organization. ${ }^{140}$

Should a true conflict be found to exist in situation (4), it appears that the $Z$ court will have to resort to a choice of law rule determined by a balancing process. In the interest of predictability and uniformity, and considering the types of conflicting policies involved, the rule referring to the place of trust organization would probably be the one best suited and most readily accepted. ${ }^{141}$

\section{CONCLUSION}

In planning for future trust organization and operation, the only guideline that may be stated with much confidence is that trust business with $Y$ states should be avoided wherever possible. If the trust is not going to transact business within a given $Y$ state, then the sale of shares within that state may possibly be undertaken without subjecting those investors to personal liability if sued in $Y_{{ }^{142}}$ Notwithstanding the possible results suggested in this comment, to encourage the transaction of business or even the sale of shares in a $Y$ state would seem inadvisable. When the trust has determined the states in which it will do business, an explicit provision in the trust instrument listing these states would be beneficial to preclude any implications of consent by the shareholders to be bound by the laws of other states. At any rate, declaring a specific purpose to do business in a $Y$ state should be avoided carefully. If it is decided that the trust is going to risk doing business in a $Y$ state, then at least there should be an evaluation of that state's laws and policies regarding the liability of shareholders in noncomplying foreigu corporations. Furthermore, an attempt should be made to comply with the $Y$ state's regulatory laws directed at foreigu corporations.

The prospective litigant who already is involved in relations with a $Y$ state would seem to have a strong argument for beneficiary immunity. While the strength of this argument may depend on the force of Currie's theory, there nevertheless is support in the results indicated in case law.

Perhaps the most hopeful prospect concerning the present conflict of laws problem is that state legislation eventually will erase the conflict. Two states formerly having $Y$ policies have already done so, ${ }^{143}$ and pressure no doubt is being exerted on the remaining $Y$ states to follow suit. ${ }^{144}$

Julius A. Shafran

1399 R.I. 446, 11 Am. Rep. 283 (1870). See text accompanying note 81 supra.

140 See cases cited in note 112 supra.

141 See discussion in part III, following note 31 supra; Note, The Real Estate Investment Trust in Multistate Activity, 48 VA. L. Rev. 1125, 1146 (1962).

142 Potential investors would doubtless have to be apprised of the risk of individual liability in any prospectus relating to the sale of trust shares.

143 See note 5 supra.

144 See, e.g., Jones, Business Trusts in Florida-Liability of Shareholders, 14 U. FLA. L. REv. 1 (1961). 